\title{
Особливості взаємодії магнітно-абразивного інструменту з оброблюваною поверхнею в умовах кільцевої ванни
}

\begin{abstract}
Досліджено особливості поведінки магнітно-абразивного інструменту (МАI) $i$ характер зміни сил переважно фрикційного походження, щзо виникають під час магнітно-абразивної обробки (МАО) циліндричних зразків діаметром 16 мм, виготовлених з феро-, пара- і діамагнітних матеріалів, щзо виникають у робочих зазорах кільцевого типу шириною 35 мм залежно від швидкості обертання навколо осі кільиевої ванни в діапазоні 100-300 об/хв, частоти обертання навколо власної осі від 0 до 80 рад/с, при магнітній індукиї в зонах обробки 0,18 і 0,25 Тл, магнітноабразивних порошкових матеріалів різного типу та розміру. Показано, щьо величина ефективного моменту тертя змінюється в діапазоні від 0 до 1,4 Нм. Ідентифіковано три області технологічних умов МАО: 1) область формування квазістійкого магнітно-абразивного інструменту; 2) область стабільно сформованого МАI; 3) область з аномальним зростанням / падінням сил тертя. Аналіз отриманих закономірностей дозволив ідентифікувати прочеси, пов'язані з особливостями поведінки частинок МАІ в процесі МАО при безпосередньому контакті з робочою поверхнею, а також умови утворення зон заклинювання, щзо виникають між полюсними наконечниками і поверхнею деталей. Показано, щз використання порошків з округлою формою частинок при МАО в зазначених вище умовах обробки забезпечує переважне пластичне деформування поверхневого шару зразків з пара- $і$ діамагнітних матеріалів. Найбільше на зміну сил фрикційного походження впливає зростання розміру частинок магнітно-абразивних порошків. Вплив зміни сил магнітного поля в досліджуваному діапазоні несуттєвий.
\end{abstract}

Ключові слова: магнітно-абразивна обробка; сили тертя; пара-, діа- $i$ феромагнітні матеріали; магнітно-абразивні порошки; контактна взаємодія.

Актуальність теми. Забезпечення ефективної фінішної обробки з використанням рухомо скоординованого магнітним полем абразивного інструменту неможливе без інформації про його властивості, розуміння умов його структурування, формування i переформування протягом технологічного циклу обробки, даних про процеси і їх особливості, що відбуваються під час контактної взаємодії з робочою поверхнею. Зазначена інформація особливо актуальна і важлива при розробці технології магнітно-абразивної обробки деталей складної просторової конфігурації на верстатах 3 великими зазорами кільцевого типу. Об'ємна обробка деталей подібного типу, до яких належать лопатки ГТД, непереточувані твердосплавні різальні пластини, осьовий і кінцевий різальний інструмент, має забезпечувати не тільки формування по всіх робочих поверхнях заданої, рівномірної шорсткості, що оцінюється такими параметрами, як Ra, Rz, tp, сіткою мікронерівностей, а й формування радіусів округлення різальних кромок на інструменті, вхідних і вихідних кромок лопаток з одночасним зміцненням поверхні деталей з необхідними градієнтами зміни поверхневої твердості, залишковими напруженнями в поверхневому шарі. Важливо зазначити той факт, що вказані характеристики, як правило, формуються на заключних операціях виготовлення деталей i в умовах сучасного виробництва, передбачають використання різних технологічних методів фінішної обробки з використанням енергій електричних, магнітних, акустичних, вібраційних полів. Метод МАО, реалізований в умовах великих кільцевих робочих зазорів для фінішної обробки складнопрофільних деталей [1], дозволяє успішно вирішувати зазначені вище завдання на однотипному обладнанні, без великої кількості технологічних переходів.

Аналіз останніх досліджень і публікацій, на які спираються автори. Процес МАО в умовах великих робочих зазорів кільцевого типу деталей складної просторової форми реалізується в режимі рівномірного обтікання оброблюваних поверхонь, що забезпечується за умови формування раціонального градієнта магнітного поля в зонах обробки, виконання певних вимог як при базуванні деталей, так і виборі відповідної траєкторії їх переміщення щодо квазінерухомого магнітно-абразивного інструменту з його заданими і контрольованими, специфічними властивостями, які визначаються та забезпечуються на підставі вимог, що ставляться до якості обробки. Зазначена гама властивостей МАI залежить не тільки від складу застосовуваних магнітно-абразивних порошків, способів їх отримання, форм і розмірів частинок, магнітних характеристик, абразивної та поліруючої здатності, а й реологічних властивостей магнітноабразивного інструменту, що формується безпосередньо в процесі МАО. Зазначені властивості МАI залежать від форми та геометрії його структурних складових у вигляді конусоподібних і веретеноподібних 
формувань [2], «мертвих зон» поблизу полюсних наконечників [1], ущільнень, що утворюються в МАI перед деталями [3], процесів, пов'язаних з переформуванням порошку. Саме зазначені параметри визначають ступінь ударної і фрикційного взаємодії МАІ з робочою поверхнею і безпосередньо впливають як на формування мікрорельєфу поверхонь, величини і форму різальних кромок, вхідних і вихідних кромок лопаток [2, 5-8], так і на особливості утворення зміцнених поверхневих шарів.

3 урахуванням специфічних умов контактування MAI з поверхнею деталей під час MAO [2, 4] зміцнення активно реалізується як при ударній взаємодії окремих об'ємів і структурних елементів МАI 3 поверхнями деталей, аналогічно процесам, що відбуваються під час струменево-абразивної обробки [9], так і безпосередньо при триботехнічному контакті [10], в процесі тертя, скобління і мікрорізання елементів MAI поверхні деталей. В результаті фрикційної і ударної взаємодій здебільшого в поверхневих шарах деталей відбуваються структурні зміни, змінюється напружено-деформований стан i, як наслідок, можуть відбуватися процеси, пов'язані зі зміцненням або знеміцненням матеріалу. Тому важливим аспектом під час розробки технології фінішної обробки рухливого скоординованого магнітним полем інструментом $\epsilon$ визначення раціонального поєднання (накладення) процесів, що реалізуються при ударному i фрикційному контакті MAI з поверхнею деталей при МАО.

Виконаний раніше теоретичний аналіз показників інтегральної енергії, що передається оброблюваній поверхні магнітно-абразивним інструментом при МАО в умовах великих робочих зазорів і залежить від сил нормального і тангенціального походження, що визначають умови ударного і фрикційного контактів, дозволив орієнтовно оцінити величину раціонального співвідношення між зазначеними силами для різних ділянок робочих поверхонь інструментів, таких як кінцевий і осьовий різальний інструмент [11-13], багатогранні непереточувані різальні пластини [1, 5], лопатки ГТД [14].

Експериментальні дослідження в зазначеному напрямі дозволили виконати тільки оцінку результату дії вказаного комплексу сил за такими непрямими показниками, як зміна шорсткості поверхні, поверхневої твердості, залишкове напруження в поверхневому шарі деталей після МАО $[1,2,5]$. Однак встановити конкретно внесок від дії сил нормального і тангенціального походження при взаємодії ділянок оброблюваних поверхонь 3 окремими структурними елементами MAI не можливо через відсутність конкретної інформації про значення реальних сил. Окремі дослідження, наведені в [2, 3, 15], є недостатніми. Тому завдання 3 визначення (встановлення) конкретних сил фрикційного і ударного походження $\epsilon$, безсумнівно, актуальними і мають розглядатися, якщо можна, окремо 3 одночасною розробкою відповідних методик досліджень.

Метою роботи було визначення реальних сил, що виникають при переважній фрикційній взаємодії оброблюваних поверхонь, виготовлених з різних матеріалів магнітно-абразивними порошками, що різняться розмірами і формою частинок, магнітними властивостями залежно від умов МАО в кільцевій ванні і особливостей контактної взаємодії МАI з поверхнею деталей.

Викладення основного матеріалу. Експериментальні дослідження виконували при МАО однакових циліндричних зразків, виготовлених з феромагнітної сталі 40X13, парамагнітних сплавів алюмінію Д16Т, титану ВТ8 і діамагнітного мідного сплаву БрОЦ (відносна магнітна сприйнятливість сплаву $\chi \approx-0,1 \cdot 10^{-6}$ Гн/м). Обробка виконувалася на експериментальному стенді для МАО деталей складної просторової конфігурації з кільцевою робочою зоною діаметром 200 мм, при ширині робочих зазорів 35 мм і висоті зони активної обробки 30 мм $[2,3,5]$. Стенд забезпечує обертання деталей навколо осі кільцевої ванни 3 регульованою частотою 50-500 об/хв, обертання деталей навколо власної осі з частотою, що змінюється в діапазоні 100-800 об/хв. При цьому забезпечується можливість контрольованого базування деталей у робочій зоні стенду як по відношенню до площини обертання в діапазоні кутів нахилу осі деталей $-p=0$ $80^{\circ}$, так і в площині, дотичній до окружності кільцевої ванни $-q=0-60^{\circ}$. Величина магнітної індукції в робочому зазорі кільцевої ванни, вільному від магнітно-абразивного порошку, може плавно регулюватися від 0 до 0,3 Тл. Стенд оснащений вимірювальним блоком, що дозволяє контролювати величини напруги i струму, споживаного двигуном постійного струму, який забезпечує обертання деталей навколо власної осі 3 певною частотою обертання деталей в процесі обробки. Для визначення значень сил тертя, що виникають між поверхнею деталей і MAI у процесі обробки, використовували модифіковану методику, описану в [2, 16], яка дозволяє визначити величину моменту від сил тертя, що виникають у парі реального контакту між поверхню зразків, що обертаються, і MAI, і певною мірою проаналізувати нюанси поведінки МАI при MAO.

Зразки з досліджуваних матеріалів базувалися в центральній частині робочих зазорів вертикально, тобто коли вісь їхнього обертання була паралельна осі кільцевої ванни при $p=0^{\circ}$ i $q=0^{\circ}$. Для забезпечення умов, за яких MAI в процесі всього циклу обробки зберігає стабільні характеристики і форму, використовували відновлювальний стрижневий елемент, який розташовувався в робочій зоні під кутом, обраним за рекомендаціями, наведеними в $[1,3]$. Для обробки використовували два типи магнітноабразивних порошків, отриманих методом розпилення з розплавів - Полімам-М і Ферромап [17, 18], 3 розміром частинок 200/100 і 415/20 мкм. Важливо зазначити, що вибір даних порошкових матеріалів був зроблений, виходячи зі ступеня їх рівновісності і форми частинок. Так порошок Полімам-М належить до 
нерівновісних округлих порошків, а Ферромап - до осколкових рівновісних. Геометричні характеристики порошків наведені в [17]. Діаметр експериментальних циліндричних зразків становив 16 мм, а висота відповідала висоті зони активної обробки - 30 мм. Діаметр зразків був обраний таким чином, щоб 3 урахуванням раніше отриманих результатів [1, 2] зберігалася можливість для подальшого аналізу особливостей переформування МАI при МАО як діа- і парамагнітних, так і феромагнітних матеріалів.

Експериментальні дослідження виконували при двох значеннях магнітної індукції в робочих зазорах 0,18 і 0,25 Тл. Процес тарування вимірювальної схеми виконувався перед кожною серією дослідів 3 метою врахування впливу як магнітного поля, так і тертя в вузлах мінішпинделя в реальних умовах процесу МАО.

Дослідження щодо впливу на зміну величини моменту від сил тертя умов обробки - швидкостей обертання навколо осі кільцевої ванни, навколо власної осі, величини магнітної індукції в робочих зазорах, типу і розмірів використовуваних магнітно-абразивних порошків були розділені на дві групи:

- обробка феромагнітних зразків зі сплаву 40X13;

- обробка пара- і діамагнітних зразків зі сплавів Д16Т, ВТ 8 і БрОЦ.

На першому етапі досліджували характер зміни величини ефективного моменту тертя, що виникає при МАО сплаву 40Х13 залежно від частоти обертання навколо власної осі циліндричних зразків при різних магнітній індукції в робочих зазорах, типі і розмірі використовуваних магнітно-абразивних порошків. Характерні залежності наведено на рисунку 1.
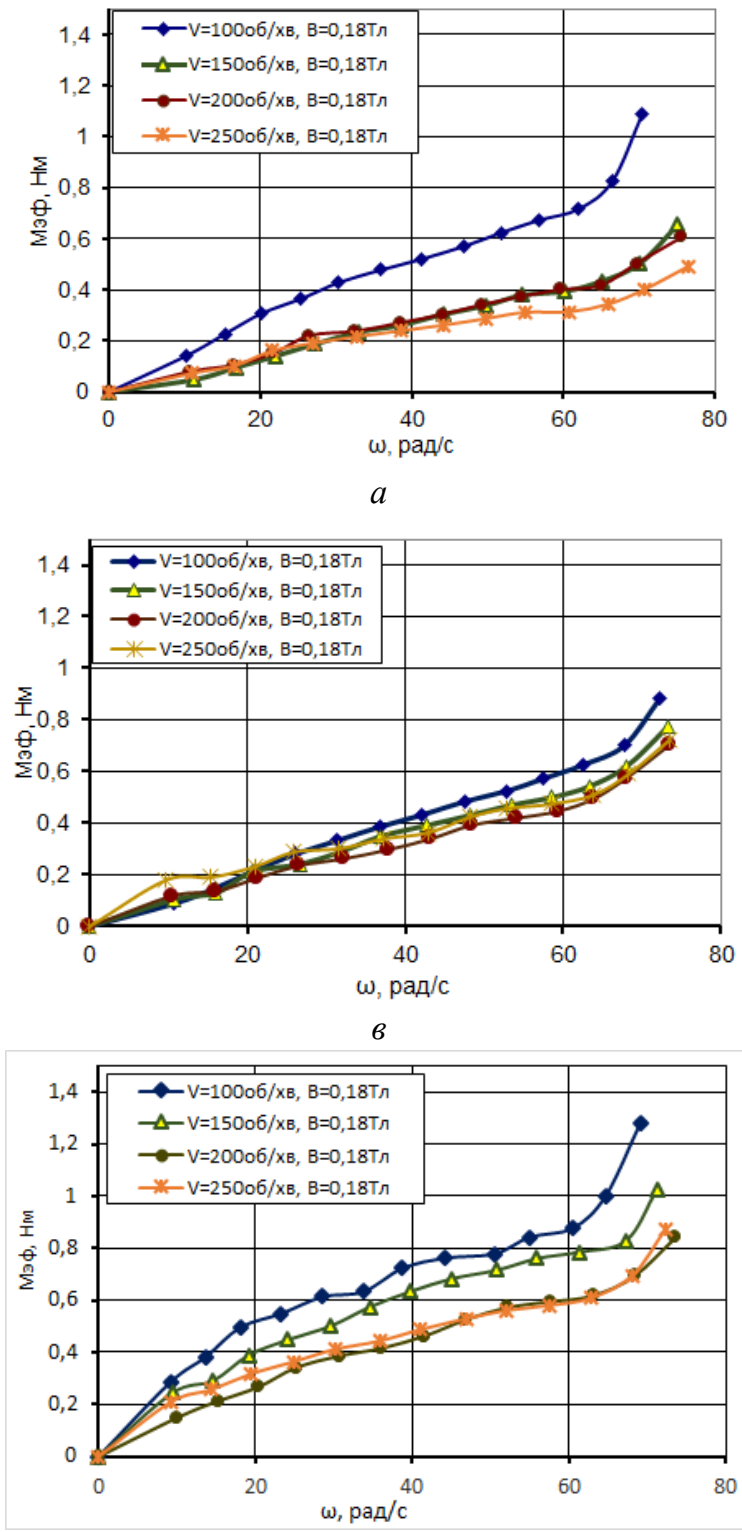

$\partial$

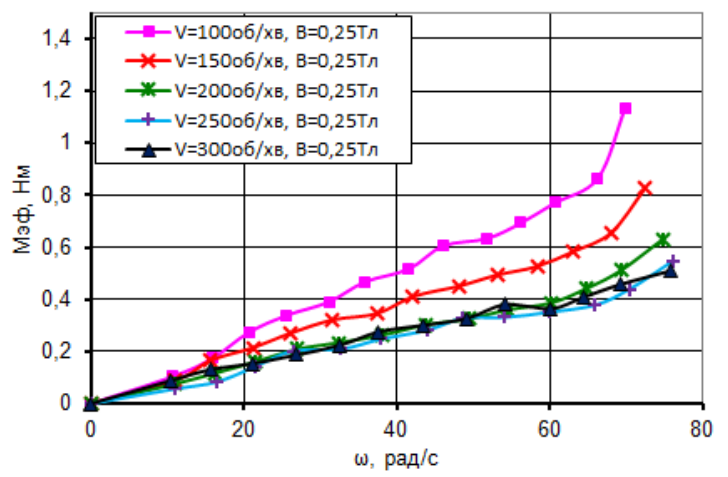

$\sigma$
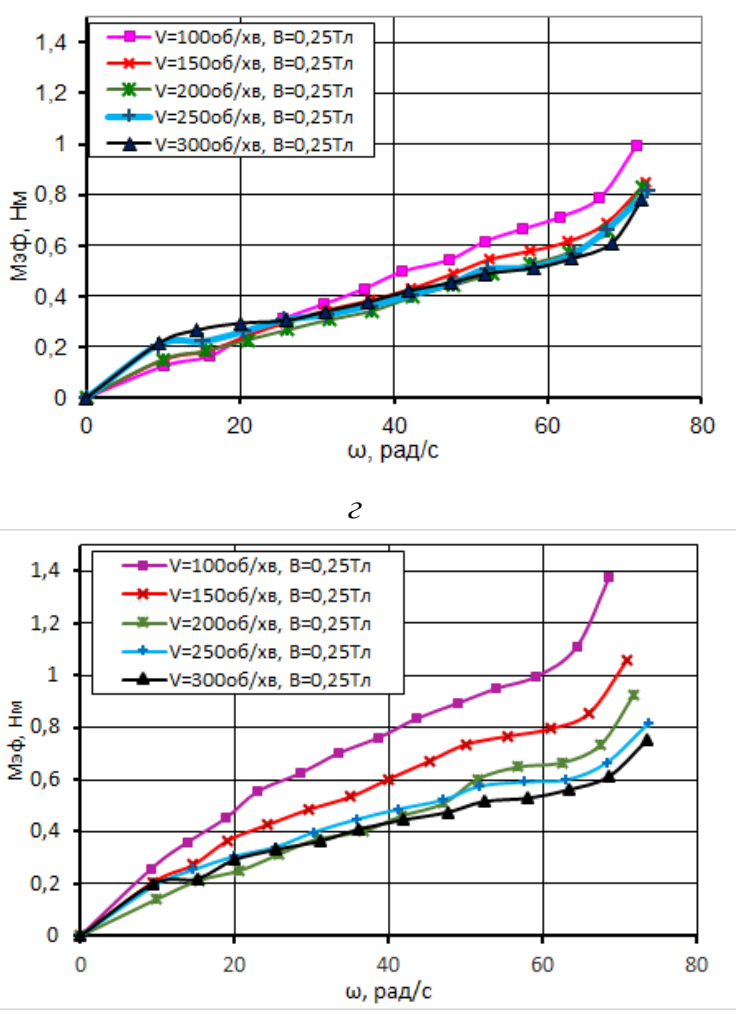

$e$ 

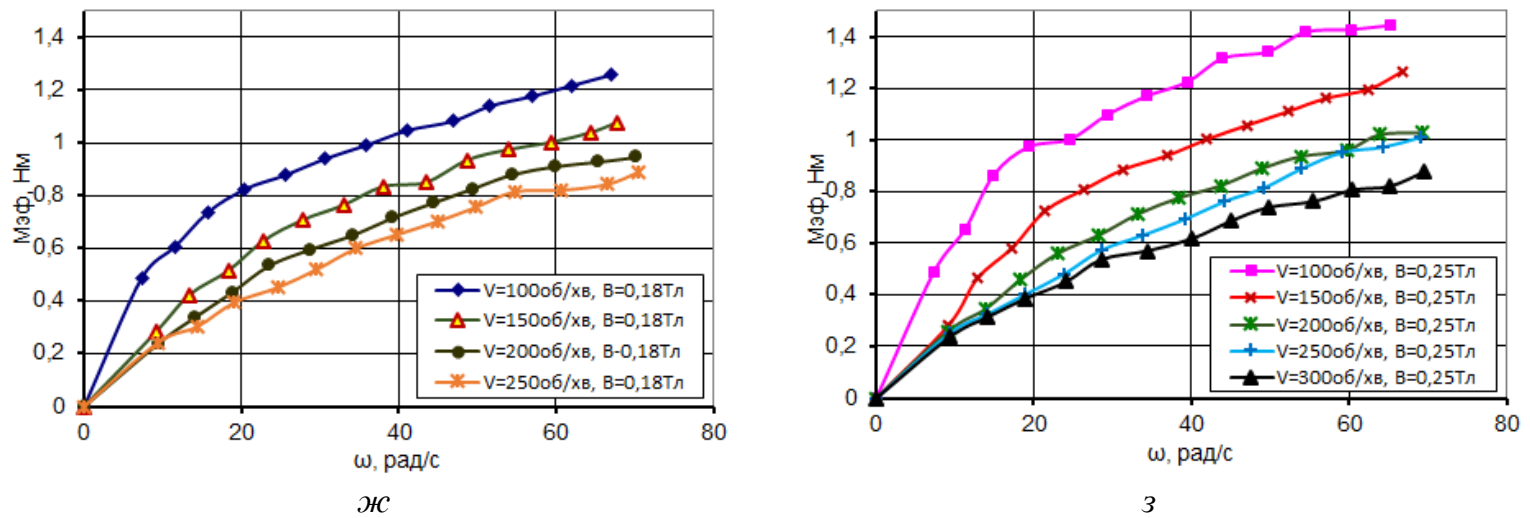

Рис. 1. Зміна величини ефективного моменту тертя при МАО сплаву $40 X 13$ порошками Ферромап (a-2) і Полімам-M - (д-з) з розмірами частинок 200/100 мкм - (a, б, д, е) i 400/315 мкм - (6, 2, ж, з) залежно від частоти обертання зразків навколо власної осі при різній магнітній індукції в робочих зазорах і частоті обертання навколо осі кільцевої зони

Аналіз результатів показав, що отримані залежності можна умовно розділити на три області:

- область формування в робочому зазорі квазістабільного і структурованого магнітно-абразивного інструменту, яка розташовується в діапазоні частот обертання зразків навколо власної осі - 0 - (5-10) рад/с;

- область зміни частоти обертання зразків (5-10) - (65-70) рад/с, де має місце практично лінійне зростання ефективного моменту $-M_{\mathrm{e \phi}}=\varphi_{\mathrm{T}} \cdot \omega_{o}$ залежно від частоти обертання навколо власної осі $-\omega_{o}$.

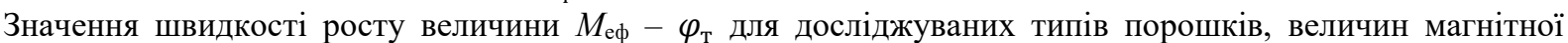
індукції в робочих зазорах $-B$ і частоти обертання навколо осі кільцевої ванни - $V_{0}$ наведені в таблиці 1 .

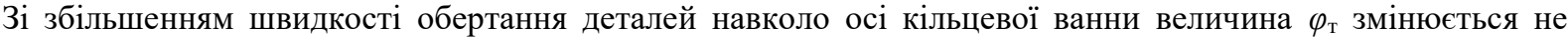
значно в бік свого зменшення, що можна пояснити зміною розмірів структурних формоутворень в MAI i характером «обтікання» магнітно-абразивним інструментом оброблюваних поверхонь [2, 3]. Збільшення магнітної індукції в робочих зазорах сприяє зростанню магнітних сил, що притягають елементи MAI до поверхні деталі і відповідно до зростання питомих сил тертя. Особливо активно це має місце під час збільшення розміру частинок і при МАО порошком Полімам-М, який має величину намагніченості в 1,3 раза вище, ніж у порошку Ферромап [2, 8];

- область в діапазоні частот обертання зразків навколо осі кільцевої ванни - більше 65-70 рад/с, де в ряді випадків (особливо при обробці порошком Ферромап) має місце різке зростання ефективного моменту, що, мабуть, пов'язано з особливостями переформування MAI в робочих зазорах, що проявляється в активному переміщенні частинок порошку, який в результаті дії магнітних сил і сил динамічного походження, що виникають під час обертання навколо осі кільцевої ванни і передаються групам порошку в процесі обертання деталей навколо осі кільцевої ванни, притискається до оброблюваної поверхні. Від дії сил тертя, що виникають при обертанні зразків навколо власної осі, порошок зміщується в область так званої «мертвої зони» - між полюсним наконечником і поверхнею деталі і розташовується безпосередньо на поверхні полюсних наконечників [1]. У результаті цього в зазначеній зоні формується область в МАІ з підвищеною щільністю, тобто відбувається формування стабільних, практично нерухомих ущільнених зон, які ідентичні зонам заклинювання $[19,20]$, що утворюються при виході деталей із зони активної обробки при МАО циліндричних поверхонь на верстатах типу ФАС.

Показано, що при МАО феромагнітної сталі практично на усіх залежностях $M_{\mathrm{eф}}=f\left(V_{0}, \omega_{0}\right)$ характерним $\epsilon$ зменшення $M_{\text {eф }}$ при збільшенні технологічного параметра $V_{0}$. В окремих випадках зменшення досить значне. Особливо подібне зменшення характерне для умов МАО округлим порошком Полімам-М і осколкових Ферромап з розміром частинок 200/100 мкм при швидкостях $V_{0}=100-150$ об/хв. Найбільші значення величини $M_{\text {еф}}$, як правило, досягаються при МАО деталей зі швидкістю обертання навколо осі кільцевої ванни $V_{0}=100$ об/хв. Це перш за все пов'язано з магнітними властивостями оброблюваного матеріалу - феромагнітної сталі. Так при швидкості в районі $V_{0}=100-150$ об/хв сила динамічного притискання порошкового MAI, що діє на частину оброблюваної площі зразків, буде нижче сил магнітного походження, які забезпечують активне притягнення частинок MAI практично до всієї оброблюваної циліндричної поверхні. Тому і зміна магнітної індукції в робочих зазорах більш-менш

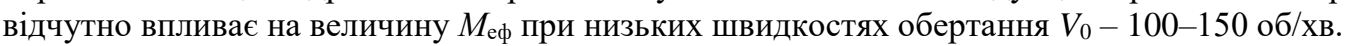


Таблиця 1

Величини швидкості росту ефективного моменту від тертя в парі МАI - оброблювана поверхня - $\varphi_{\mathrm{T}}$ залежно від частоти обертання зразків навколо власної осі

\begin{tabular}{|c|c|c|c|c|c|c|c|}
\hline \multirow{2}{*}{$\begin{array}{c}\text { Тип } \\
\text { порошку }\end{array}$} & \multirow{2}{*}{$\begin{array}{c}\text { Размір } \\
\text { частинок, } \\
\text { мкм }\end{array}$} & \multirow{2}{*}{ В, Тл } & \multicolumn{5}{|c|}{ Частота обертання навколо осі кільцевої ванни $V_{o}$, об/хв } \\
\cline { 4 - 8 } & & 100 & 150 & 200 & 250 & 300 \\
\hline \multirow{3}{*}{ Ферромап } & \multirow{2}{*}{$200 / 100$} & 0,18 & 0,0106 & 0,0071 & 0,0065 & 0,0048 & \\
\cline { 3 - 8 } & \multirow{2}{*}{$400 / 315$} & 0,25 & 0,0130 & 0,0089 & 0,0063 & 0,006 & 0,00585 \\
\cline { 3 - 8 } & 0,25 & 0,102 & 0,0085 & 0,0075 & 0,0066 & \\
\hline \multirow{3}{*}{ Полімам-М } & \multirow{2}{*}{$200 / 100$} & 0,18 & 0,011 & 0,0092 & 0,0084 & 0,0074 & 0,0063 \\
\cline { 3 - 8 } & \multirow{2}{*}{$400 / 315$} & 0,25 & 0,0145 & 0,0104 & 0,0089 & 0,0076 & \\
\cline { 3 - 8 } & 0,25 & 0,011 & 0,0113 & 0,0102 & 0,0077 & 0,0069 \\
\hline
\end{tabular}

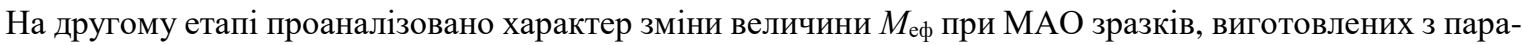
і діамагнітних матеріалів. Отримані результати експериментальних досліджень після їх статистичної обробки зазначені у вигляді топограм поверхонь функціями виду $M_{\mathrm{eф}}=f\left(V_{0}\right.$, $\left.\omega_{0}\right)$, отриманих при використанні зазначених вище порошкових матеріалів і магнітних індукціях у робочих зазорах. Характерні топограми поверхонь $M_{\text {еф }}=f\left(V_{0}, \omega_{0}\right)$ для парамагнітних зразків зі сплавів алюмінію наведені на рисунку 2, титану - на рисунку 3 , а діамагнітного сплаву міді - на рисунку 4.
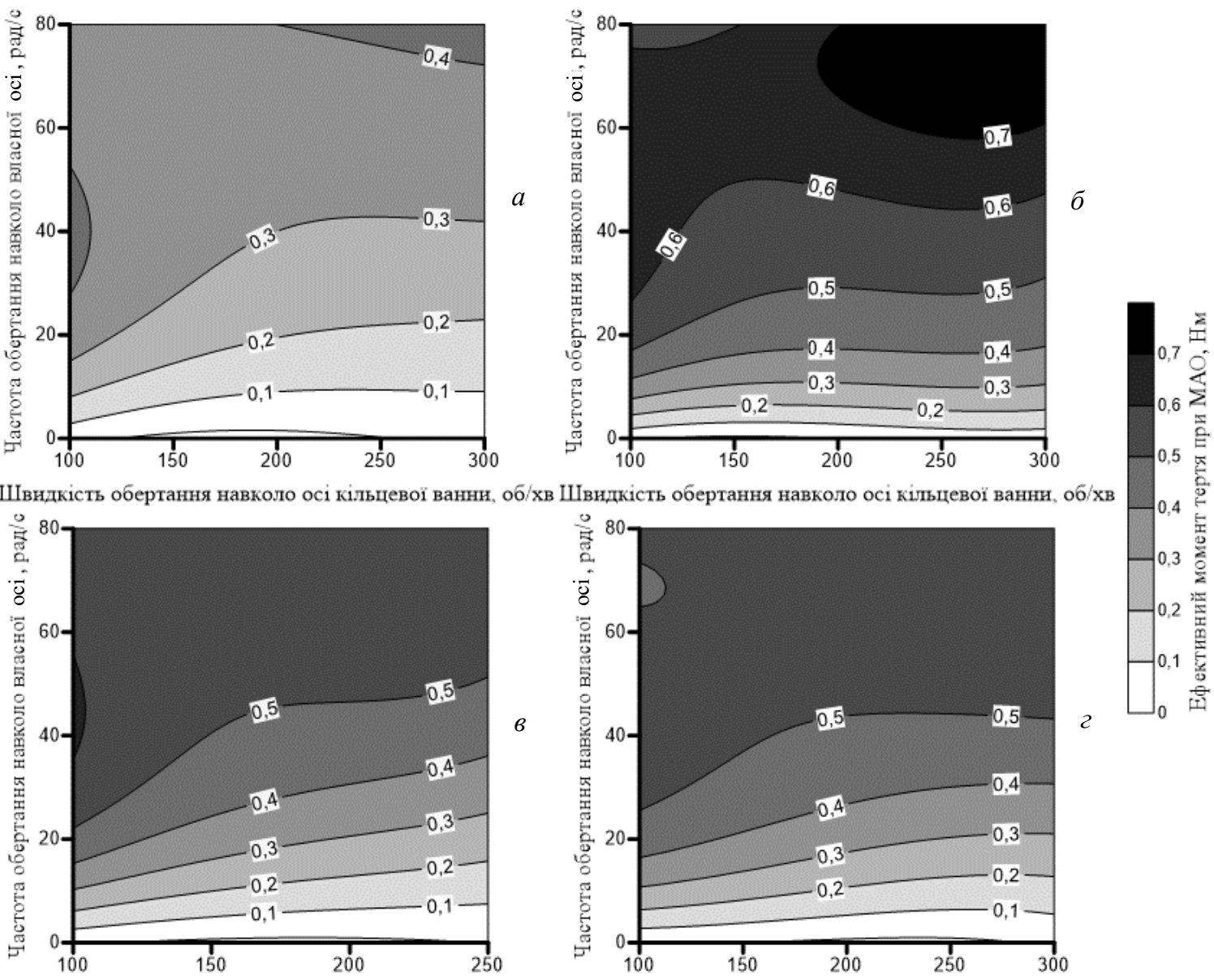

Швидкість обертання навколо осі кільцевої ванни, об/хв Швидкість обертання навколо осі кільцевої ванни, об/хв

Рис. 2. Зміна величини ефективного моменту тертя при МАО сплаву Д16Т порошками Ферромап (а, б) і Полімам-M - (в, г) з розмірами частинок 200/100 мкм - (a, в) i 400/315 мкм - (б, г) залежно від частоти обертання зразків навколо власної осі і швидкості обертання навколо осі кільцевої зони при магнітній індукиії в робочих зазорах 0,18 Тл- (а, в) і 0,25 Тл- $(6$, г) 


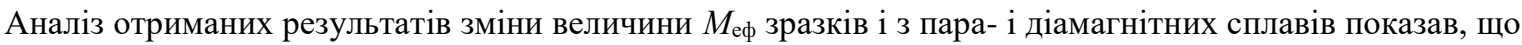

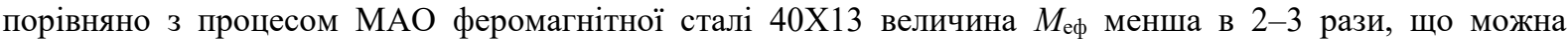
пояснити дією суттєво менших сил магнітного походження при взаємодії елементів MAI з поверхнею пара- і діамагнітних зразків і 50 \% зменшенням площі поверхні зразків, що піддається активній обробці, де виконуються умови для забезпечення ефективного процесу МАО [1].

Зауважимо, що якщо при МАО сталевих зразків при частотах обертання навколо власної осі більше за 60-65 рад/с має місце різке зростання величини $M_{\text {еф}}$, то при обробці немагнітних матеріалів на першому

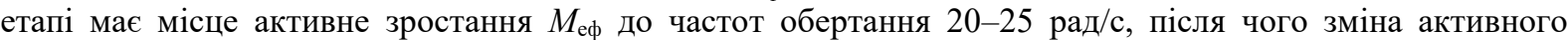
моменту тертя або незначна, або відсутня, а при частотах понад 60 рад/с здебільшого відбувається його зниження. Це може свідчити про те, що, починаючи з частот обертання навколо власної осі 20-25 рад/с, проявляється активне провертання окремих частинок МАI щодо оброблюваної поверхні, що найбільш характерно для порошків 3 округлою формою частинок. При цьому змінюється механізм контактної взаємодії, коли сили тертя ковзання, що сприяють реалізації процесів мікрорізання і мікроскобління, переходять в тертя кочення, тобто здійснюється активне провертання частинок МАI щодо оброблюваної поверхні, що призводить до переважної мікропластичної деформації поверхні деталей.

Слід зазначити і той факт, що при підвищених частотах обертання зразків навколо власної осі - більше за 60 рад/с явище «заклинювання» порошку в мертвій зоні активно не проявляється.
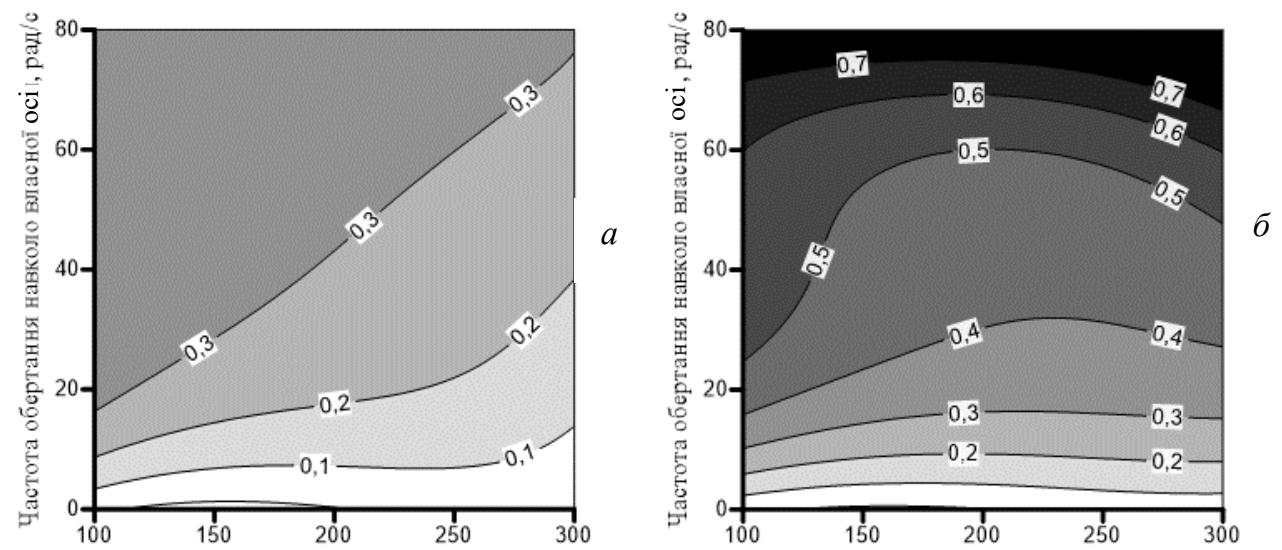

Швидкість обертання навколо осі кільцевої ванни, об/хв Швидкість обертання навколо осі кільцевої ванни, об/хв
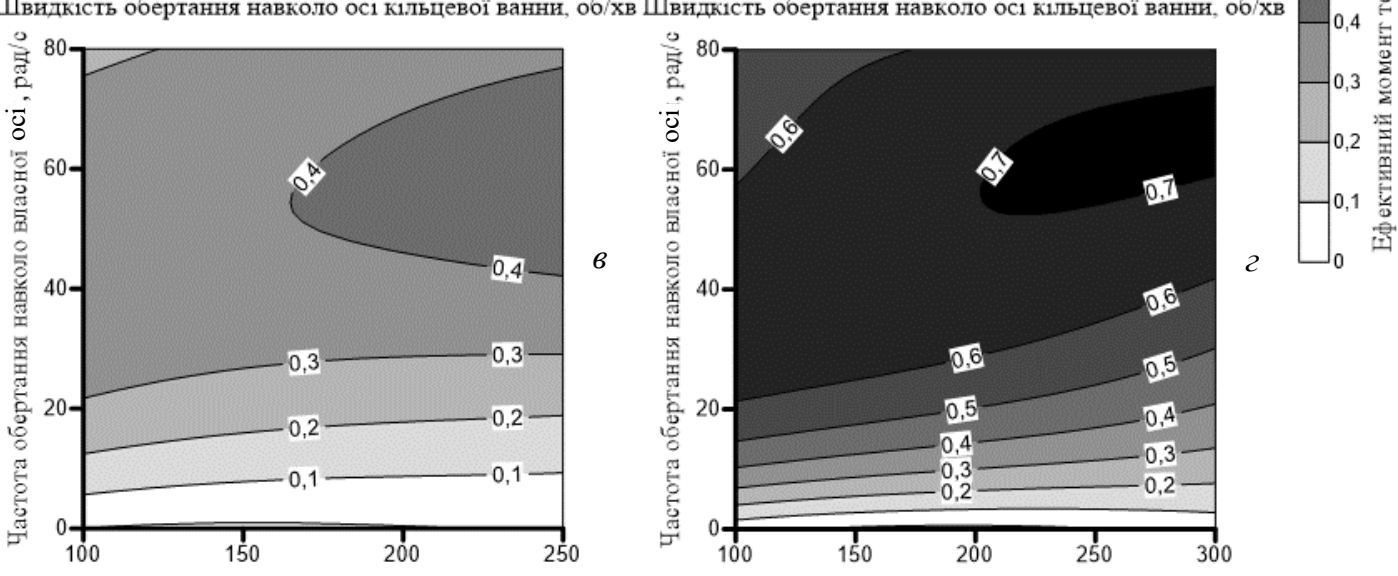

Швидкість обертання навколо осі кільцевої ванни, об/хв Швидкість обертання навколо осі кільцевої ванни, об/хв

Рис. 3. Зміна величини ефективного моменту тертя при МАО сплаву ВТ8 порошками Ферромап (а, б) і Полімам-M -(в, г) з розмірами частинок 200/100 мкм - (а, в) i 400/315 мкм - (б, г) залежно від частоти обертання зразків навколо власної осі і швидкості обертання навколо осі кільцевої зони при магнітній індукиї в робочих зазорах 0,18 Tл- $($ а, в) $і$ 0,25 Тл- $(б$, г)

Підтвердженням цього $є$ зовнішній вигляд поверхні зразків 3 пара- і діамагнітних матеріалів зі слідами мікропластичної деформації, яка реалізується в умовах активного провертання частинок щодо оброблюваної поверхні (рис. 5, $a-8$ ) і слідами мікрорізання і мікроскобління на феромагнітних деталях у режимі тертя ковзання, без активного кочення зерен МАІ щодо поверхні сталевих зразків (рис. 5, 2). Зазначимо, що найбільша мікропластичної деформація характерна для зразків зі сплаву БрОЦ, який більш пластичний порівняно з Д16Т і ВТ8. 
Для визначення ступеня впливу розміру часток MAI і магнітної індукції в робочих зонах магнітних

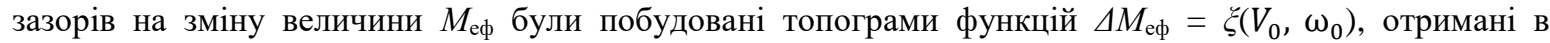
результаті віднімання функцій поверхонь $M_{\mathrm{eф}}=f\left(V_{0}, \omega_{0}\right)$ для різних значень магнітних індукцій і розмірів частинок порошків.

Типові топограми поверхонь функцій $\Delta M_{\mathrm{e \phi}}=\xi\left(V_{0}, \omega_{0}\right)$, отриманих шляхом віднімання функцій $M_{\text {еф }}=f\left(V_{0}, \omega_{0}\right)$, при різних значеннях магнітної індукції в робочих зазорах $-0,18$ і 0,25 Тл, тобто

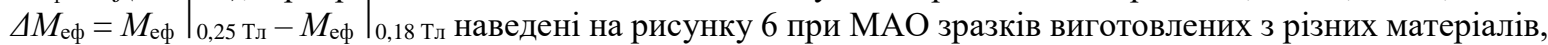
порошками різного типу і з різною зернистістю.

Для зразків, виготовлених з парамагнітних матеріалів зі збільшенням розміру частинок від 200/100 до 400/315 мкм, зміна ефективного моменту тертя при зазначених вище магнітних індукціях у робочих зазорах не перевищує 0,35 Нм. Найбільша зміна має місце при підвищених швидкостях обертання як навколо власної осі, так і навколо осі кільцевої ванни і магнітної індукції 0,25 Тл при використанні для формування MAI осколкових порошків Ферромап.

Показано, що магнітне поле в зазначеному вище діапазоні істотно не впливає на зміну ефективного моменту тертя в парі поверхня деталі - MAI. Зміна ефективного моменту не перевищує 10-15\% від максимальних значень, які мають місце при МАО різних сплавів різними порошками в зазначених вище діапазонах зміни параметрів обробки. Аналіз вказаних топограм показує, що найбільша відмінність у значеннях ефективного моменту тертя при збільшенні магнітної індукції в зонах обробки від 0,18 до 0,25 Тл проявляється в основному при підвищених значеннях $V_{0}$ i $\omega_{0}$, що пов’язано, як зазначалося вище, з формуванням ущільнень в МАI в області «мертвих зон» у поверхні полюсних наконечників.
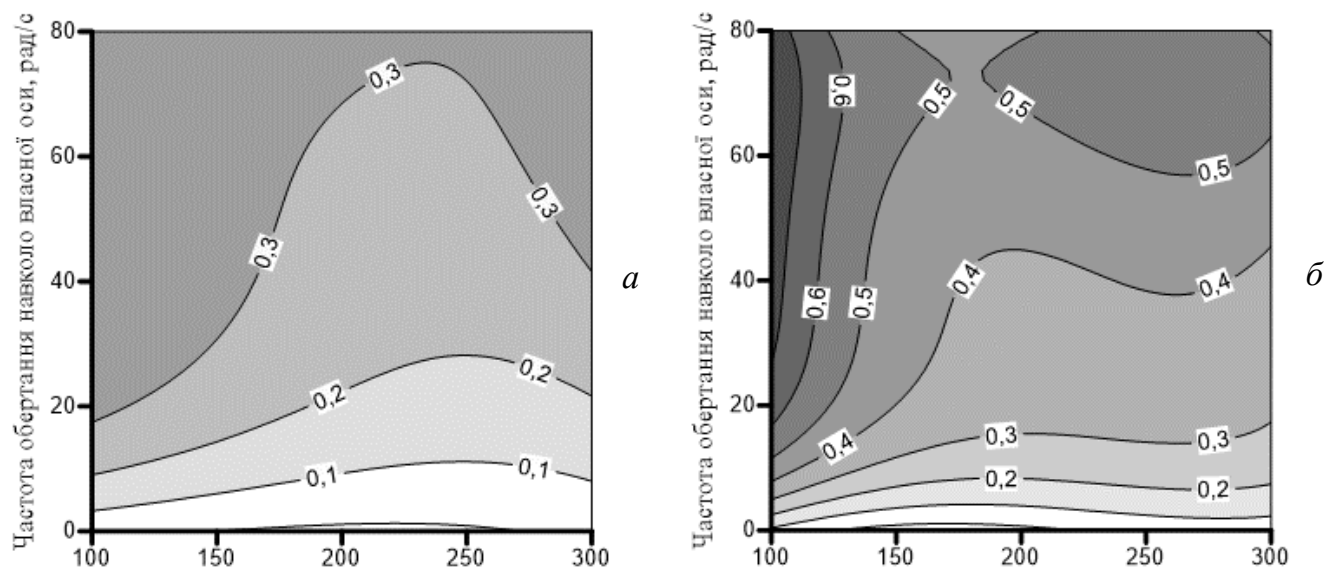

Швидкість обертання навколо осі кільцевої ванни, об/хв Швидкість обертання навколо осі кільцевої ванни, об/хв
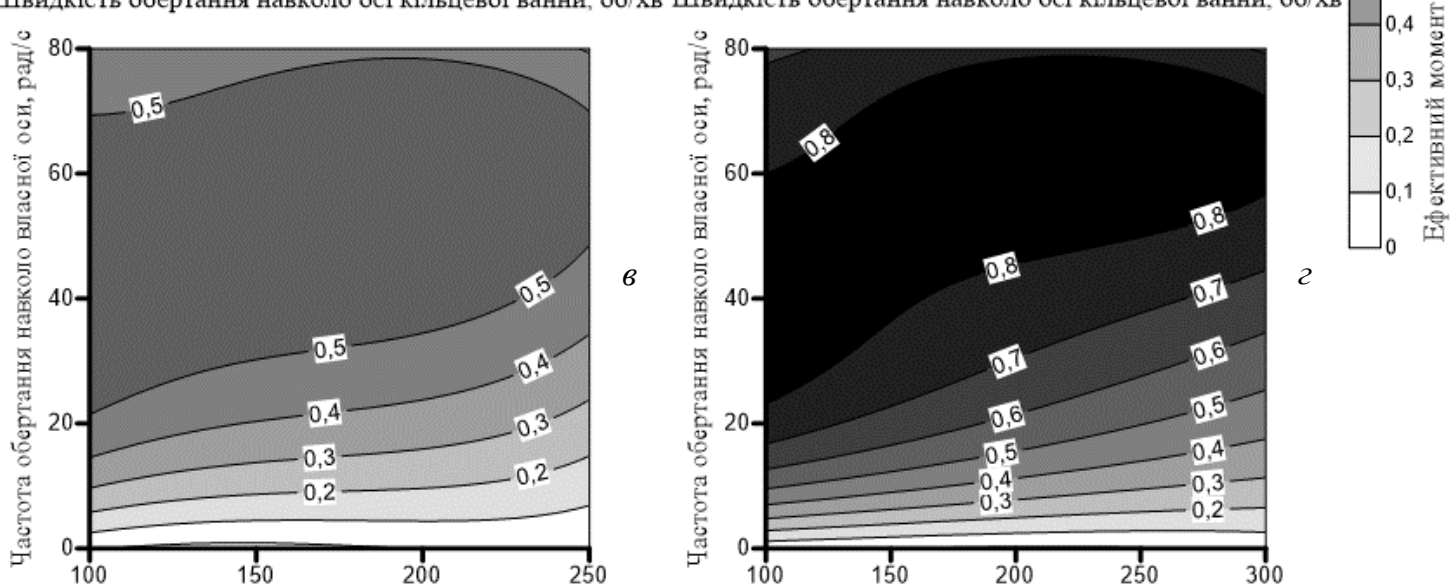

Швидкість обертання навколо осі кільцевої ванни, об/хв Швидкість обертання навколо осі кільцевої ванни, об/хв

Рис. 4. Зміна величини ефективного моменту тертя при МАО діамагнітного сплаву БрОЦ порошками Ферромап - (а, б) і Полімам-M - (в, г) з розмірами частинок 200/100 мкм - (а, в) i 400/315 мкм - (б, г) залежно від частоти обертання зразків навколо власної осі і швидкості обертання навколо осі кільцевої зони при магнітній індукції в робочих зазорах $0,18 T_{л}-(a, 6)$ i 0,25 Тл- $(6$, г) 


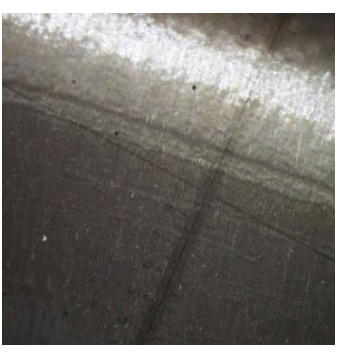

$a$

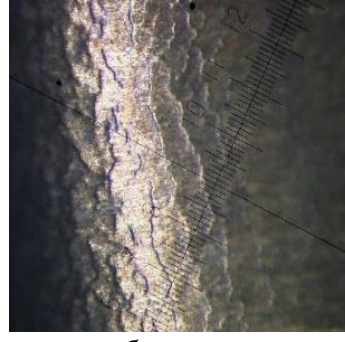

6

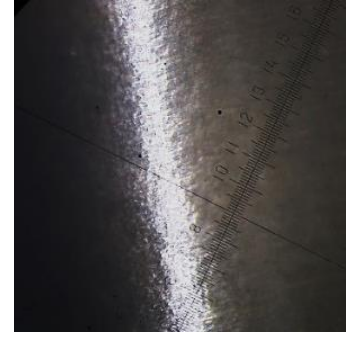

B

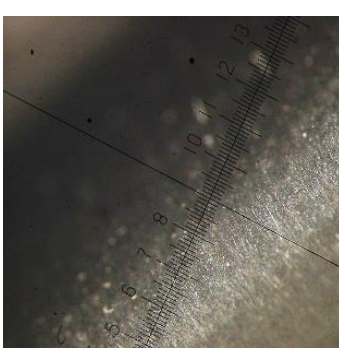

Рис. 5. Зовнішній вигляд поверхні зразків зі сплавів ВТ 8-а, БрОЦ - б, Д16Т - в, 40Х13 - г після МАО

Типові топограми функцій $\Delta M_{\mathrm{eф}}=\xi\left(V_{0}, \omega_{0}\right)$, отриманих шляхом віднімання функцій $M_{\mathrm{eф}}=f\left(V_{0}, \omega_{0}\right)$, що одержані в результаті МАО порошками з різним розміром частинок - 400/315 і 200/100 мкм при фіксованому значенні магнітної індукції в зонах обробки, тобто $\Delta M_{\mathrm{e} \phi}=M_{\mathrm{e} \phi} .\left.\right|_{400 / 315}-\left.M_{\mathrm{e} \phi}\right|_{200 / 100} 3$ зазначені на рисунку 7.

При обробці округлим порошком Полімам-М найбільші значення величини $\Delta M_{\mathrm{e \phi}}-$ до 0,25-0,3 Нм проявляються при швидкостях обертання навколо осі кільцевої ванни в діапазоні 120-170 об/хв і частотах обертання навколо власної осі - 20-25 рад/с. При обробці діамагнітного сплаву міді зона 3 найбільшими

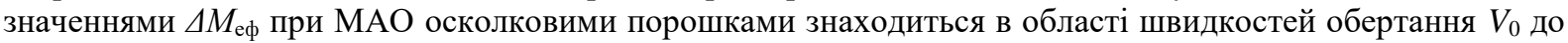
100-150 об/хв, а округлим порошком Полімам-М в області більше 200-250 об/хв. Це пов'язано з суттєвою різницею в значеннях коефіцієнтів внутрішнього тертя між шарами порошків [2] i, відповідно, особливостями переформування і руху частинок порошку в локальних мікрооб'ємах МАI в безпосередній близькості від оброблюваної поверхні діамагнітних деталей, пов'язаних з дією пондеромоторних сил, що сприяють змінам у локальних мікрооб'ємах сил магнітного походження.
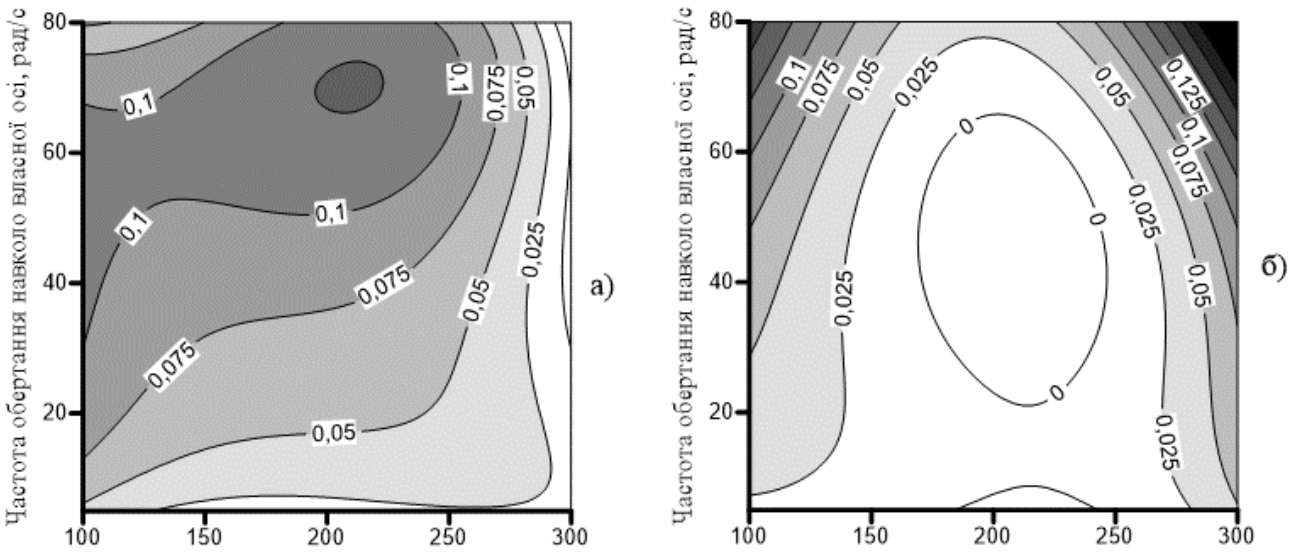

Швидкість обертання навколо осі кільцевої ванни, об/хв Швидкість обертання навколо осі кільцевої ванни, об/хв
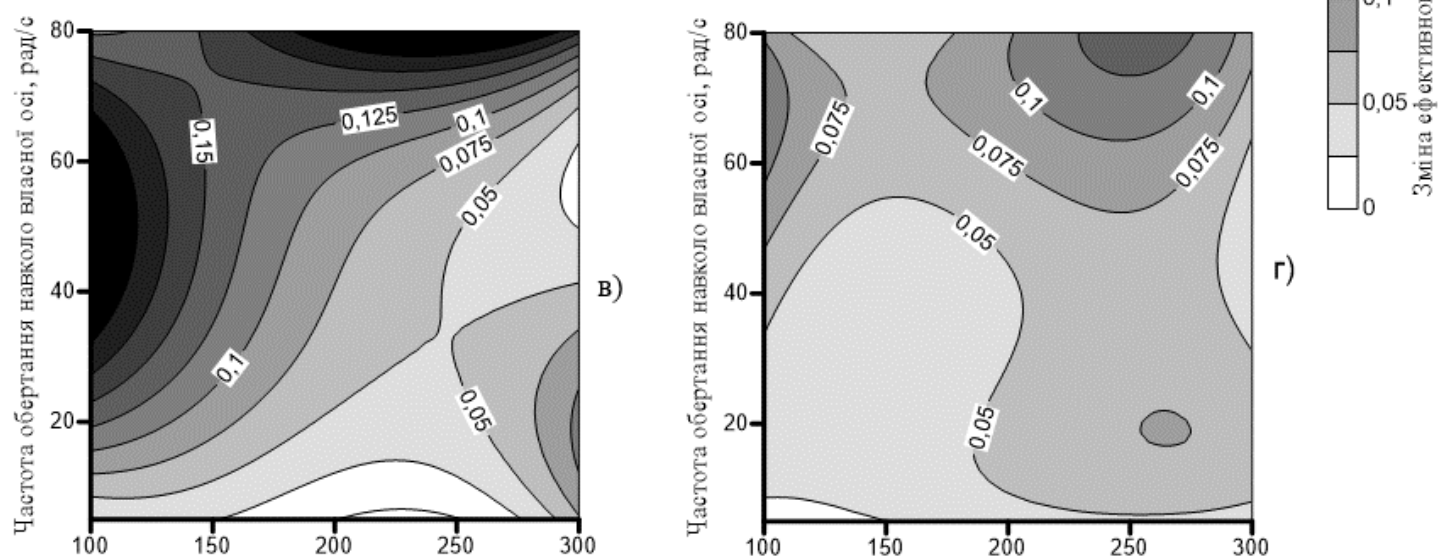

Швидкість обертання навколо осі кільцевої ванни, об/хв Швидкість обертання навколо осі кільцевої ванни, об/хв

Рис. 6. Зміна ефективного моменту тертя, щуо визначається збільшенням магнітної індукції в робочих зонах від 0,18 до 0,25 Тл при обробці зразків, виготовлених зі сплаву титану BT8 - (a, б) $і$ сталі - (в, г) при МАО порошком Ферромап з розміром частинок 400/315 мкм - (б, г), Полімам-М з розміром частинок 200/100 мкм - (а) і 400/315 мкм - (в) 

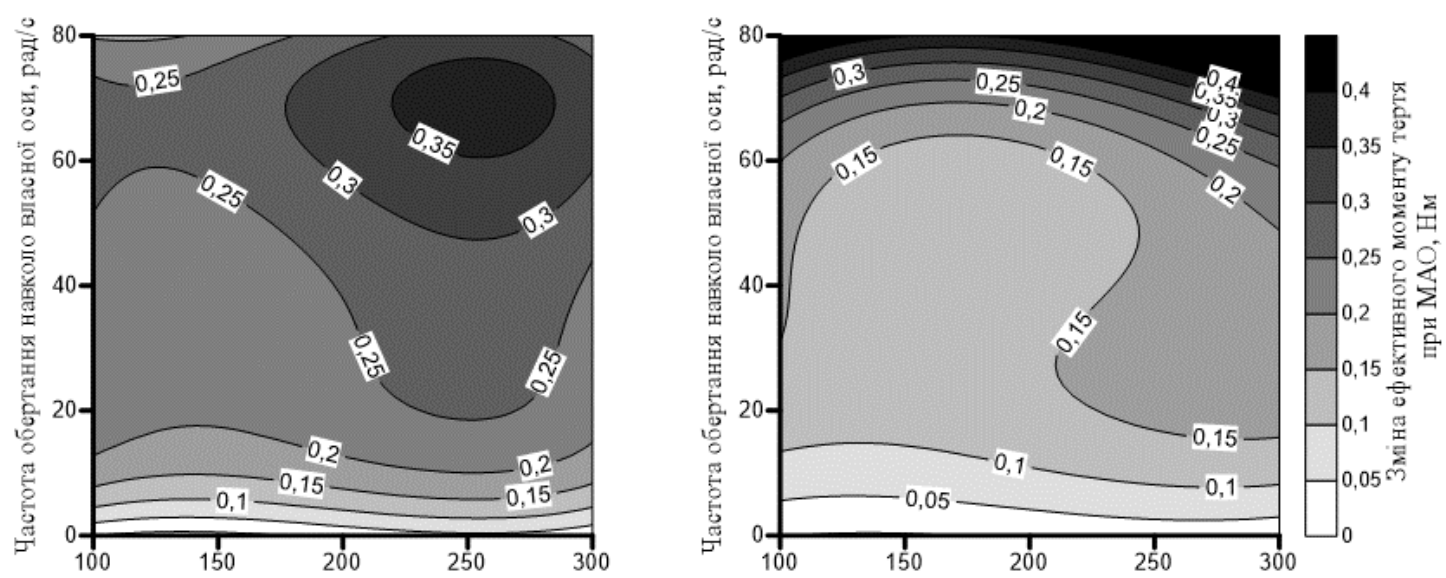

Швидкість обертання навколо осі кільцевої ванни, об/хв Швидкість обертання навколо осі кільцевої ванни, об/хв

$a$

Рис. 7. Зміна ефективного моменту тертя, щчо визначається збільшенням розміру часток порошку Ферромап від 200/100 до 400/315 мкм при обробці зразків, виготовлених зі сплаву алюмінію -(а) і сплаву титану - (б) при МАО з магнітною індукиією в робочих зазорах 0,25 Тл

Аналогічна, але протилежна дія пондеромоторних сил проявляється при МАО сталевих зразків, коли збільшення розміру частинок MAI, сформованого з порошку Полімам-М, призводить до зростання питомих сил тертя на величину більше за 0,3-0,4 Нм при частотах обертання навколо власної осі деталей 50-65 рад/с (рис. 8).
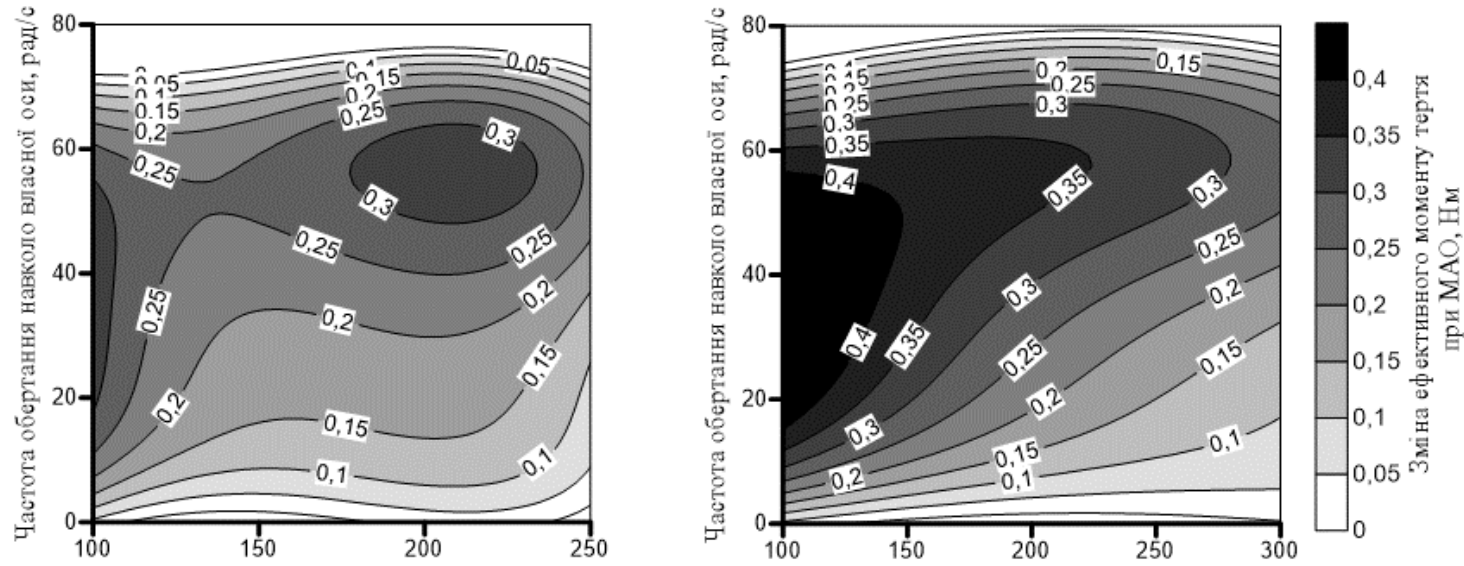

Швндкість обертання навколо осі кільцевої ванни, об/хв Швндкість обертання навколо осі кільцевої ванни, об/хв

$a$

$\sigma$

Рис. 8. Зміна ефективного моменту тертя, яке пов'язане зі збільшенням розміру частинок порошку

Полімам-М від 200/100 до 400/315 мкм при обробиі зразків, виготовлених зі сталі 40Х13, при МАО з магнітною індукиією в робочих зазорах 0,18Тл-(а) $i$ 0,25 Тл- (б)

Висновки. Досліджено особливості поведінки магнітно-абразивного інструменту і характер зміни сил переважно фрикційного походження, що виникають при магнітно-абразивній обробці циліндричних зразків діаметром 16 мм, виготовлених з феро, пара- і діамагнітних матеріалів, що виникають у робочих зазорах кільцевого типу шириною 35 мм залежно від швидкості обертання навколо осі кільцевої ванни в діапазоні 100-300 об/хв, частоти обертання навколо власної осі від 0 до 80 рад/с, при магнітній індукції в зонах обробки 0,18 і 0,25 Тл, типу і розмірів магнітно-абразивних порошкових матеріалів. Показано, що величина ефективного моменту тертя змінюється в діапазоні від 0 до 1,4 Нм. Встановлено області технологічних умов МАО, за яких відбувається формування квазістійкого магнітно-абразивного інструменту, область стабільно сформованого MAI, і область з аномальним зростанням / падінням сил тертя. Аналіз отриманих закономірностей дозволив ідентифікувати процеси, пов'язані з особливостями поведінки частинок MAI в процесі MAO при безпосередньому контакті з робочою поверхнею, а також умови утворення зон заклинювання, що виникають між полюсними наконечниками і поверхнею деталей. Показано, що використання порошків з округлою формою частинок при МАО в зазначених вище умовах обробки забезпечує переважне пластичне деформування поверхневого шару зразків з пара- і діамагнітних матеріалів. Найбільше на зміну сил фрикційного походження впливає зростання розміру часток магнітноабразивних порошків. Вплив зміни сил магнітного поля в досліджуваному діапазоні несуттєвий. 


\section{Список використаної літератури:}

1. Майборода B.C. Магнитно-абразивная обработка деталей сложной формы / B.C. Maйборода, И.В. Слободянюк, Д.Ю. Джулий. - Житомир : ПП «Рута», 2017. - 272 с.

2. Майборода B.C. Основи створення і використання порошкового магнітно-абразивного інструменту для фінішної обробки фасонних поверхонь : дис. ... докт. техн. наук / В.С. Майборода. - Київ, $2001 .-404$ с.

3. Ткачук I.B. Формування магнітно-абразивного інструменту зі стабільними властивостями в робочих зазорах кільцевого типу : дис. ... канд. техн. наук : 05.03.01 / I.B. Ткачук. - Київ, 2015. - 164 с.

4. Акулович Л.М. Магнитно-абразивная обработка сложнопрофильных поверхностей деталей сельскохозяйственных машин / Л.М. Акулович, Л.Е. Сергеев. - Минск : БГАТУ, 2019. - 272 с.

5. Джулій Д.Ю. Підвищення якості багатогранних непереточуваних твердосплавних пластин при магнітноабразивному обробленні в кільцевій ванні : дис. ... канд. техн. наук : 05.03.01 / Д.Ю. Джулій. - Київ, 2014. $175 \mathrm{c}$.

6. Byelyayev $O$. Erhöhung der Leistungsfähigkeit von HSS-Spiralbohrern durch Einsatz der magnetabrasiven Bearbeitung : PhD. Thesis / O.Byelyayev ; Otto von Guericke. - Magdeburg, Germany, 2008. -150 p.

7. Финишная обработка поверхностей при производстве деталей / С.А. Клименко, М.Ю. Копейкина, В.И. Лавриненко и др. ; под общ. ред. С.А. Чижик, М.Л. Хейфец. - Минск : Беларуская навука, $2017 .-376$ с.

8. Степанов O.B. Исследование процесса формирования магнитно-абразивного порошкового инструмента для обработки деталей сложной геометрической формы : дисс. ... канд. техн. наук : 05.16.06 / O.B. Cmenaнoв. Киев, 1997. - 145 с.

9. Проволоцкий A.E. Струйно-абразивная обработка деталей машин / A.Е. Проволоикий. - Киев : Техника, 1989. - 177 c.

10. Крагельский И.В. Основы расчетов на трение и износ / И.В. Крагельский, М.Н. Добычин, В.С. Комбалов. М. : Машиностроение, 1977. - 526 с.

11. Магнітно-абразивна обробка осьового і кінцевого різального інструменту / В.С. Майборода, Д.В. Хроновский, B.I. Солодкий, Н.В. Ульяненко // Наукові вісті НТУУ «КПІ». - 2002. - № 5. - С. 69-73.

12. Features of magneto-abrasive machining of taps / V.Maiboroda, D.Tarhan, D.Dzhulii, I.Slobodianiuk // Acta Mechanica et Automatica. - Bialystok University of Technology, Poland. - 2020. -Vol. $51 .-7$ p.

13. Тарган Д.В. Аналіз інтенсивності магнітно-абразивного оброблення мітчиків в залежності від кінематичних параметрів процесу / Д.В. Тарган, В.С. Майборода, Д.Ю. Джулій // Сучасні технології в машинобудуванні, транспорті та гірництві : Вісник КрНУ імені Михайла Остроградського.- Кременчук : КрНУ, 2017. - № 106. C. 82-88.

14. Гейчук В.M. Синтез кінематики процесу магнітно-абразивної обробки в кільцевій ванні : автореф дис. ... докт. техн. наук. : 05.03.01/ B.M. Гейчук. - К., 2012. - 40 с.

15. Івановський O.A. Формування магнітно-абразивного інструменту для оброблення свердел в умовах великих магнітних щілин : дис. ... канд. техн. наук : 05.03.01 / О.А. Івановський. - Київ, 2009. - 135 с.

16. Майборода В.С. Магнитно-абразивная обработка специальных деталей : дисс. ... канд. техн. наук : 05.02 .08 / В.С. Майборода. - К., 1988. - 170 с.

17. Ткачук I.B. Геометричні характеристики магнітно-абразивних порошків / I.B. Ткачук, В.C. Майборода // Надійність інструменту та оптимізація технологічних систем. - 2014. - № 34. - С. $49-55$.

18. Оликер B.E. Порошки для магнитно-абразивной обработки и износостойких покрытий / B.E. Oликер. Москва : Металлургия, 1990. - $176 \mathrm{c}$.

19. Барон Ю.М. Магнитно-абразивная и магнитная обработка изделий и режущих инструментов / Ю.М. Барон. Ленинград : Машиностроение, 1986. - 176 с.

20. Сакулевич Ф.Ю. Основы магнитно-абразивной обработки / Ф.Ю. Сакулевич. - Мн. : Наука и техника, 1981. $328 \mathrm{c}$.

\section{References:}

1. Maiboroda,V.S., Slobodyanyuk, I.V. and Dzhulii, D.Yu. (2017), Magnitno-abrazivnaya obrabotka detalei slozhnoi formy, PP «Ruta», Zhitomir, $272 \mathrm{p}$.

2. Majboroda, V.S. (2001), «Osnovy stvorennja i vykorystannja poroshkovogo magnitno-abrazyvnogo instrumentu dlja finishnoi' obrobky fasonnyh poverhon'», D.Sc. Thesis of dissertation, Kyi'v, 404 p.

3. Tkachuk, I.V. (2015), «Formuvannja magnitno-abrazyvnogo instrumentu zi stabil'nymy vlastyvostjamy v robochyh zazorah kil'cevogo typu», Ph.D. Thesis of dissertation, 05.03.01, Kyi'v, 164 p.

4. Akulovich, L.M. and Sergeev, L.E. (2019), Magnitno-abrazivnaya obrabotka slozhnoprofil'nykh poverkhnostei detalei sel'skokhozyaistvennykh mashin, BGATU, Minsk, 272 p.

5. Dzhulij, D.Ju. (2014), «Pidvyshhennja jakosti bagatogrannyh neperetochuvanyh tverdosplavnyh plastyn pry magnitno-abrazyvnomu obroblenni v kil'cevij vanni», Ph.D. Thesis of dissertation, 05.03.01, Kyi'v, 175 p.

6. Byelyayev, O. (2008), «Erhöhung der Leistungsfähigkeit von HSS-Spiralbohrern durch Einsatz der magnetabrasiven Bearbeitung», Ph.D. Thesis of dissertation, Otto von Guericke, Magdeburg, Germany, $150 \mathrm{p}$.

7. Klimenko, S.A., Kopeikina, M.Yu., Lavrinenko, V.I. i dr. (2017), Finishnaya obrabotka poverkhnostei pri proizvodstve detalei, in Chizhik, S.A. and Kheifets, M.L. (ed.), Belaruskaya navuka, Minsk, 376 p.

8. Stepanov, O.V. (1997), «Issledovanie protsessa formirovaniya magnitno-abrazivnogo poroshkovogo instrumenta dlya obrabotki detalei slozhnoi geometricheskoi formy», Ph.D. Thesis of dissertation, 05.16.06, Kiev, 145 p.

9. Provolotskii, A.E. (1989), Struino-abrazivnaya obrabotka detalei mashin, Tekhnika, Kiev, 177 p. 
10. Kragel'skii, I.V., Dobychin, M.N. and Kombalov, V.S. (1977), Osnovy raschetov na trenie i iznos, Mashinostroenie, M., $526 \mathrm{p}$.

11. Majboroda, V.S., Hronovskyj, D.V., Solodkyj, V.I. and Ul'janenko, N.V. (2002), «Magnitno-abrazyvna obrobka os'ovogo i kincevogo rizal'nogo instrumentu, Naukovi visti NTUU «KPI», 2002, No. 5, pp. 69-73.

12. Maiboroda, V., Tarhan, D., Dzhulii, D. and Slobodianiuk, I. (2020), «Features of magneto-abrasive machining of taps», Acta Mechanica et Automatica, Bialystok University of Technology, Poland, Vol. 51, 7 p.

13. Targan, D.V., Majboroda, V.S. and Dzhulij, D.Ju. (2017), «Analiz intensyvnosti magnitno-abrazyvnogo obroblennja mitchykiv v zalezhnosti vid kinematychnyh parametriv procesu», Suchasni tehnologii' v mashynobuduvanni, transporti ta girnyctvi, Visnyk KrNU imeni Myhajla Ostrograds'kogo, KrNU, Kremenchuk, No. 106, pp. 82-88.

14. Gejchuk, V.M. (2012), «Syntez kinematyky procesu magnitno-abrazyvnoi' obrobky v kil'cevij vanni», Abstract of D.Sc. dissertation, 05.03.01, K., 40 p.

15. Ivanovs'kyj, O.A. (2009), «Formuvannja magnitno-abrazyvnogo instrumentu dlja obroblennja sverdel v umovah velykyh magnitnyh shhilyn», Ph.D. Thesis of dissertation, 05.03.01, Kyi'v, 135 p.

16. Maiboroda, V.S. (1988), «Magnitno-abrazivnaya obrabotka spetsial'nykh detalei», Ph.D. Thesis of dissertation, 05.02.08, K., $170 \mathrm{p}$.

17. Tkachuk, I.V. and Majboroda, V.S. (2014), «Geometrychni harakterystyky magnitno-abrazyvnyh poroshkiv», Nadijnist' instrumentu ta optymizacija tehnologichnyh system, No. 34, pp. 49-55.

18. Oliker, V.E. (1990), Poroshki dlya magnitno-abrazivnoi obrabotki i iznosostoikikh pokrytii, Metallurgiya, Moskva, $176 \mathrm{p}$.

19. Baron, Yu.M. (1986), Magnitno-abrazivnaya i magnitnaya obrabotka izdelii i rezhushchikh instrumentov, Mashinostroenie, Leningrad, $176 \mathrm{p}$.

20. Sakulevich, F.Yu. (1981), Osnovy magnitno-abrazivnoi obrabotki, Nauka i tekhnika, Mn., 328 p

Майборода Віктор Станіславович - доктор технічних наук, професор Київського політехнічного інституту імені Ігоря Сікорського.

Наукові інтереси:

- фізика процесів різання;

- фінішна обробка;

- реологія порошкових середовищ у магнітному полі.

Заставський Костянтин Олегович - аспірант Київського політехнічного інституту імені Ігоря Сікорського.

Наукові інтереси:

- магнітно-абразивна обробка;

- реологія порошкових середовищ у магнітному полі;

- технологія машинобудування.

Жук Роман Борисович - магістр Київського політехнічного інституту імені Ігоря Сікорського.

Наукові інтереси:

- технологія машинобудування;

- магнітно-абразивна обробка;

- поведінка порошку в робочих зазорах.

Стаття надійшла до редакції 22.09.2021. 